\title{
Translational activation of the non-AUG-initiated c-myc 1 protein at high cell densities due to methionine deprivation
}

\author{
Stephen R. Hann", Karen Sloan-Brown, and Gerald D. Spotts \\ Department of Cell Biology, Vanderbilt University, School of Medicine, Nashville, Tennessee, 37232-2175 USA
}

\begin{abstract}
c-myc belongs to a small, yet growing, group of eukaryotic mRNAs that initiate translation inefficiently from a non-AUG codon upstream from a more efficient AUG codon. We have examined the translational regulation of non-AUG-initiated c-myc 1 and AUG-initiated c-myc 2 protein synthesis in avian and mouse cells during proliferation. As lymphoid, erythroid, and embryo fibroblast cells approached high densities in culture, there was a sustained 5- to 10-fold induction in the synthesis of c-myc 1 protein to levels $\geqslant c$-myc 2 protein synthesis. Treatment with conditioned/depleted media from high-density cells was able to reproduce this activation in low-density cells within 5 hr. Additional studies with the conditioned/depleted media revealed that amino acid availability, specifically methionine deprivation, was responsible for this unique translational control. Our results describe a specific and dramatic regulation of dual translational initiation. Furthermore, these results represent a novel translational activation of a specific gene in higher eukaryotes in response to nutrient deprivation.
\end{abstract}

[Key Words: c-myc; non-AUG initiation; amino acid deprivation; translational control]

Received January 10, 1992; revised version accepted April 9, 1992.

Although the specific function of $\mathrm{c}-m y c$ remains to be elucidated, there is increasing evidence that $\mathrm{c}-m y c$ is a transcription factor that performs a fundamental role in the control of cellular proliferation (Luscher and Eisenman 1990). The c-myc gene encodes two major nuclear phosphoproteins that are found in species ranging from Xenopus to human (Hann et al. 1988). The most abundant $c-m y c$ protein, $c-m y c 2$, initiates translation in exon 2 from the first AUG codon, whereas the $c-m y c 1$ protein initiates upstream in exon 1 at a non-AUG site (a CUG in human c-myc) (Hann et al. 1988). There are no apparent differences between these two proteins in subcellular localization, stability, or post-translational modifications (Hann and Eisenman 1984; Hann et al. 1985). A functional significance for the non-AUG-initiated c-myc 1 protein in regulating cell growth, however, is suggested by its absence in tumor-derived cell lines that have an alteration at the c-myc locus, such as in human Burkitt's lymphomas (Hann and Eisenman 1984; Hann et al. 1988).

In addition to c-myc 1, a small, yet increasing, number of other eukaryotic cellular proteins have been found to initiate translation from a non-AUG codon. These include transcription factors such as TEF-1 (Xiao et al.

${ }^{1}$ Corresponding author.
1991) and Krox-24 (Lemaire et al. 1990), a growth factor (basic fibroblast growth factor) (Florkiewicz and Sommer 1989; Prats et al. 1989), and proto-oncogenic proteins such as 1yl-1 (Mellentin et al. 1989), int-2 (Acland et al. 1990), pim-1 (Saris et al. 1991), and hck-1 (Lock et al. 1991). Whereas TEF-1 appears to initiate synthesis exclusively at the non-AUG codon, the other proteins appear to initiate preferentially at an AUG codon downstream of the non-AUG initiation codon. The functional significance of dual initiation or non-AUG initiation for these genes is unknown; however, the two int-2 and hck-1 proteins do have different subcellular localizations (Acland et al. 1990; Lock et al. 1991).

It is unclear how non-AUG initiation codons are recognized by the ribosomes or whether there is any regulation of the non-AUG versus AUG initiator codon usage. Studies that have examined the usage of non-AUG initiation in mammalian cells have generally demonstrated that the efficiency of non-AUG initiation is negligible in comparison to AUG initiation (Kozak 1989b; Peabody 1989|. Indeed, synthesis of the non-AUG-initiated c-myc 1 protein has been shown previously to be only $\sim 10-15 \%$ of the level of c-myc 2 protein synthesis in growing cells (Hann and Eisenman 1984; Hann et al. 1988).

In this paper we show that as avian lymphoid, murine erythroid, or avian embryo fibroblast cells approach high 
densities in culture, a 5- to 10-fold increase in the synthesis of the non-AUG initiated-c-myc 1 protein occurs. In contrast, synthesis of the AUG-initiated c-myc 2 is minimally affected. Therefore, the level of c-myc 1 synthesis becomes comparable to or greater than the level of AUG-initiated c-myc 2 synthesis. This translational activation of c-myc 1 at high cell densities is also achieved within hours in growing cells by the addition of conditioned/depleted media from high-density cells. Further analysis has demonstrated that this induction of c-myc 1 protein synthesis appears to be specifically mediated through methionine availability. Although amino acid deprivation is known to affect translational initiation of specific genes in yeast, most notably the transcription factor GCN4 (Abastado et al. 1991), the occurrence in higher eukaryotes of a translational increase of a specific gene in response to amino acid deprivation, as described herein, is novel. This observed shift in synthesis of the two proteins may reflect /and may be a sensitive measure of) an important change in the translational machinery as cells approach stationary phase because of nutrient depletion.

\section{Results}

To investigate the translational regulation of $c-m y c 1$ and 2 proteins during cellular proliferation, we examined c-myc protein synthesis from low cell density (exponentially growing) to high cell density (growth inhibited) in several different cultured cell types. Avian cells were used primarily because, unlike the human and mouse c-myc genes, which have two promoters (Spencer and Groudine 1991), the avian c-myc gene synthesizes only one mRNA (Nottenburg and Varmus 1986). Therefore, the potential influence of two different messages directing the synthesis of the two c-myc proteins was eliminated. In addition, as demonstrated previously for the human c-myc 1 protein, the c-myc 1 protein in avian cells initiates from an upstream non-AUG codon as determined by protease mapping experiments (Hann et al. 1988). Preliminary results indicate that this non-AUG is an AUU codon in exon 1 (G.D. Spotts and S.R. Hann, unpubl.). Figure 1 illustrates the position of this AUU codon in avian c-myc compared with the CUG codons identified as initiation sites for human (Hann et. al. 1988) and mouse c-myc 1 (S. Pfaff and S.R. Hann, unpubl.).

By use of the avian-specific antisera, anti-av-myc 12C, the two major c-myc proteins of 59,000 and 61,000 daltons, and a minor intermediate protein were immunoprecipitated from chicken embryo fibroblasts (CEFs), as shown in Figure 2A (lane 1). The minor protein of 60,000 daltons may represent a modified form of $\mathrm{c}-\mathrm{myc} 2$ or may arise from a second, minor upstream non-AUG start site for translation. This intermediate-sized protein and another minor protein of 62,000 daltons, which we often observe in avian cells, have also been detected in human and mouse cells (Hann et al. 1988). The specificity of the antibody for the c-myc proteins was confirmed by preincubating the anti-av-myc $12 \mathrm{C}$ sera with peptide to block specific immunoprecipitation (Fig. 2A, lane 2).

\section{Induction of non-AUG-initiated c-myc 1 protein synthesis in cells at high density}

The synthesis of the c-myc proteins was first examined at various times during the growth of the avian bursal lymphoma cell line Bk3A. Bk3A cells synthesized enhanced levels of c-myc RNA as a result of a proviral integration, which thereby facilitated the examination of the $\mathrm{c}-m y c$ proteins. Although Bk3A cells overexpress the $c-m y c$ proteins, they express the same c-myc protein pattern as in normal cells such as CEF cells /cf. Fig. 2,A and B). Also, Bk3A cells, unlike several other bursal lymphoma cells, were the only cells that behaved like normal CEF and MSB-1 cells in a study examining the effects of protein synthesis inhibitors on c-myc RNA synthesis and stability (Linial et al. 1985). Because c-myc proteins have rapid turnovers of $\sim 30 \mathrm{~min}$ (Hann et al. 1983,1984 ), we metabolically labeled cells with $\left[{ }^{35}\right.$ S $]$ methionine for only $20 \mathrm{~min}$ to examine the relative synthesis levels while minimizing the influence of protein turnover.

$\mathrm{Bk} 3 \mathrm{~A}$ cells were harvested at various times throughout a 4-day time course, and the c-myc proteins were immunoprecipitated after equalizing for trichloroacetic acid (TCA)-precipitable counts as described in Materials and methods. Figure 2B demonstrates that after $38 \mathrm{hr}$ in cul-
Figure 1. Predicted amino-terminal amino acid sequences of non-AUG-initiated $c-m y c 1$ proteins. The human, mouse, and chicken c-myc cDNA nucleotide and predicted amino acid-coding sequences for c-myc 1 protein amino-termini are shown. Relative molecular masses of the predicted amino-terminal peptides are in parentheses. The defined or putative upstream non-AUG and downstream AUG initiation codons are italicized, and the surrounding bases most critical for nonAUG initiation codon recognition are underlined. The asterisk $\left({ }^{*}\right)$ indicates exon 1-2 splice junctions.

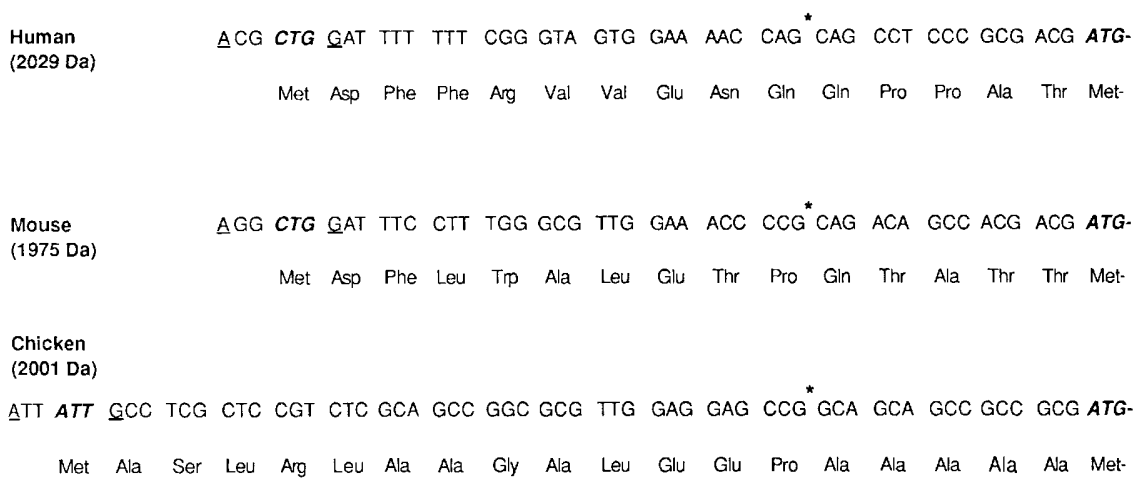



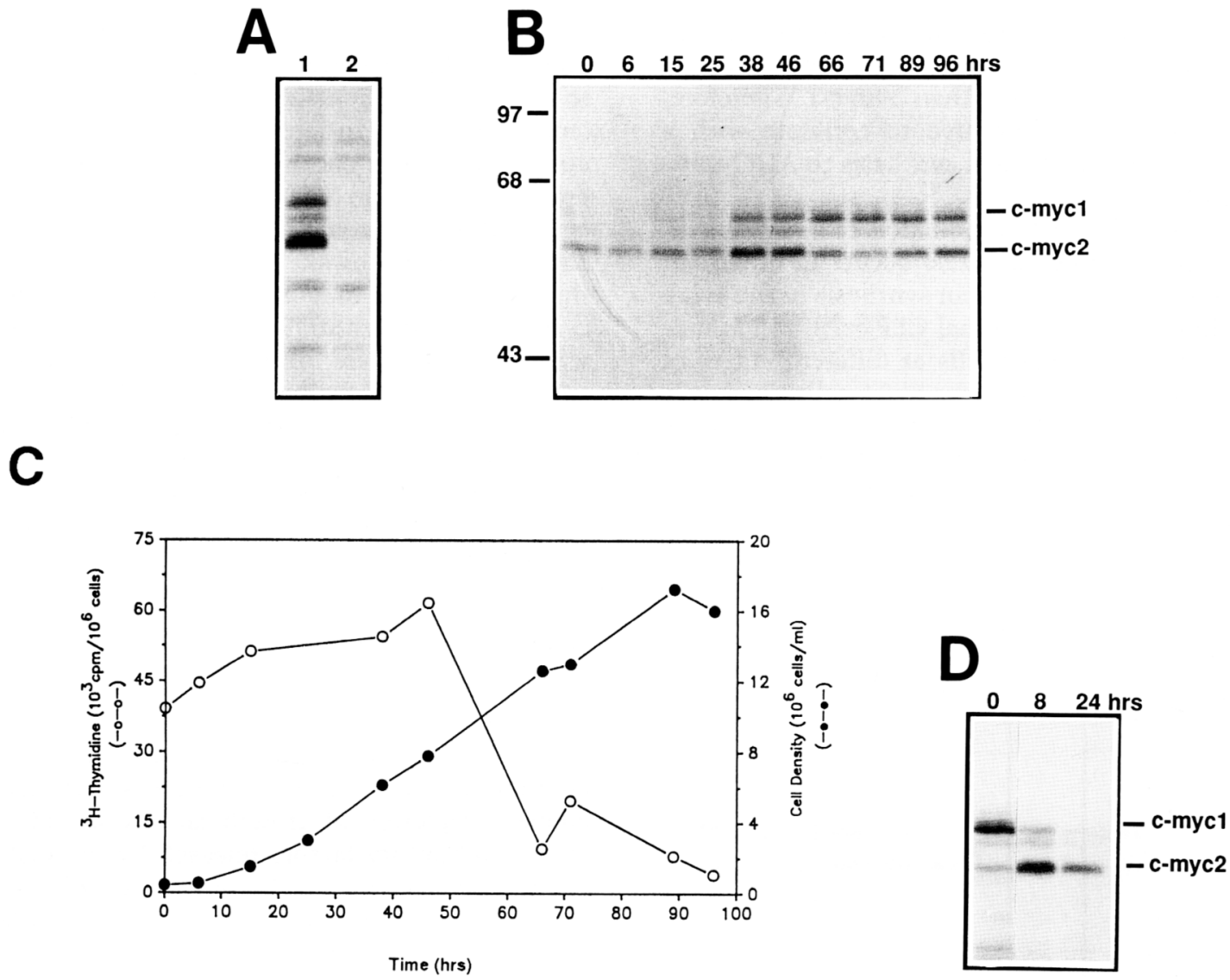

Figure 2. Regulation of c-myc 1 protein synthesis during the proliferation of Bk3A cells. $(A)$ Secondary CEF cells were pulse-labeled with $300 \mu \mathrm{Ci}$ of $\left[{ }^{35} \mathrm{~S}\right]$ methionine for $20 \mathrm{~min}$ and lysed with $\mathrm{Ab}$ buffer. Equal amounts of lysate were then incubated with anti-av-myc $12 \mathrm{C}$ or anti-av-myc $12 \mathrm{C}$ that had been preincubated with the av-myc $12 \mathrm{C}$ peptide. Following immunoprecipitation, the samples were electrophoresed on a $10 \%$ SDS-polyacrylamide gel. (B) Exponentially growing BK3A cells were seeded at $5 \times 10^{5}$ cells $/ \mathrm{ml}$ in fresh SCM and grown in roller bottles without refeeding for $96 \mathrm{hr}$. At the indicated times, $10^{7}$ cells were pulse-labeled with $300 \mu \mathrm{Ci}$ of $\left.{ }^{35} \mathrm{~S}\right]$ methionine for $20 \mathrm{~min}$. After lysing the cells in Ab buffer, lysates were adjusted to equal amounts of incorporated label and the c-myc proteins were immunoprecipitated with anti-av-myc $12 \mathrm{C}$ antibody. The samples were electrophoresed on a $10 \%$ SDS-polyacrylamide gel. A fluorograph of the dried gel with standard molecular mass markers (molecular mass $\left.\times 10^{3}\right)$ is shown. Relative levels of c-myc 1 and 2 were determined by densitometric analysis. $(C) \mathrm{Bk} 3 \mathrm{~A}$ cell number and $\left[{ }^{3} \mathrm{H}\right]$ thymidine incorporation per $10^{6}$ cells during the time course described in $B$. The cell number was determined at the indicated times. At each time point, $10^{7}$ cells were labeled for $20 \mathrm{~min}$ with $5 \mu \mathrm{Ci}$ of $\left[{ }^{3} \mathrm{H}\right]$ thymidine, and aliquots of lysates were precipitated onto filters with TCA to determine incorporation of label into DNA (reported as $10^{3} \mathrm{cpm} / 5 \times 10^{5}$ cells). (D) c-myc protein synthesis in Bk3A cells at saturation density and after dilution in fresh medium. Bk3A cells were grown as described above to saturation density $\left(10^{7}\right.$ cells $\left./ \mathrm{ml}\right)$ and then diluted with fresh SCM to $2 \times 10^{5}$ cells $/ \mathrm{ml}$. At saturation density (time 0) and 8 and $24 \mathrm{hr}$ post-dilution, $10^{7}$ cells were pulse-labeled with $\left[{ }^{35} \mathrm{~S}\right]$ methionine. The $\mathrm{c}-\mathrm{myc}$ proteins were immunoprecipitated as described above.

ture, there was a dramatic and sustained increase in c-myc 1 synthesis relative to $c-m y c 2$. On the basis of densitometric analysis, c-myc 1 synthesis was $\sim 15 \%$ of c-myc 2 synthesis at low cell densities $(0-25 \mathrm{hr})$ and increased fivefold to levels equivalent to or greater than c-myc 2 synthesis as the cells approached saturating density $(66-96 \mathrm{hr})$. Synthesis of the non-AUG-initiated c-myc 1 protein reached maximal levels $(38-66 \mathrm{hr})$ as the cells reached $\sim 50 \%$ cell density (i.e., the majority of the cells had not completed the final round of mitosis). DNA synthesis, as measured by $\left[{ }^{3} \mathrm{H}\right]$-thymidine incorporation, decreased dramatically during this same period (Fig. 2C) suggesting that the majority of the cells were no longer progressing through S-phase. Unlike DNA synthesis, however, there was no significant decrease in total cellular protein synthesis during this period as determined by $\left.{ }^{35} \mathrm{~S}\right]$ methionine incorporation (data not shown). This was also confirmed by our observation that the synthesis of $c-m y b$, another transcription factor, did not change significantly during this period (data not shown).

To determine whether the high level of c-myc 1 synthesis could be affected by reinitiating growth, cells at high density were diluted 10-fold into fresh growth medium. Figure 2D shows that in the cells grown to high density (time 0), c-myc 1 was synthesized at a fourfold higher level than c-myc 2. Within $8 \mathrm{hr}$ after the cells 
were diluted 10-fold with fresh medium, c-myc 1 synthesis was repressed while c-myc 2 synthesis was induced to levels fourfold higher than c-myc 1. Therefore, restimulation of growth appeared to correlate with a switch from non-AUG-initiated synthesis to AUG-initiated synthesis of c-myc.

To determine whether the induction of $\mathrm{c}-\mathrm{myc} 1 \mathrm{syn}$ thesis observed in Bk3A cells also occurs in other cell types, we examined c-myc protein synthesis in the avian thymocyte line, MSB-1, in normal CEF cells, and in murine erythroleukemia (MEL) cells at different stages of proliferation. As observed with the Bk3A cells, the levels of c-myc 1 synthesis were low in growing MSB-1 cells (Fig. 3A, lanes 1-3). At saturation density (lane 4), c-myc 1 synthesis increased $\sim 10$-fold to levels equivalent to or

A
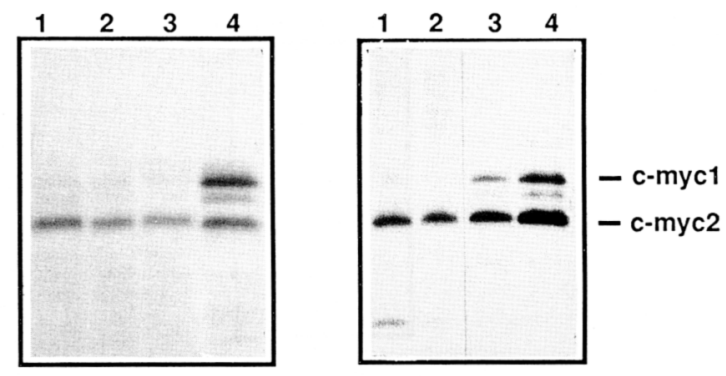

C

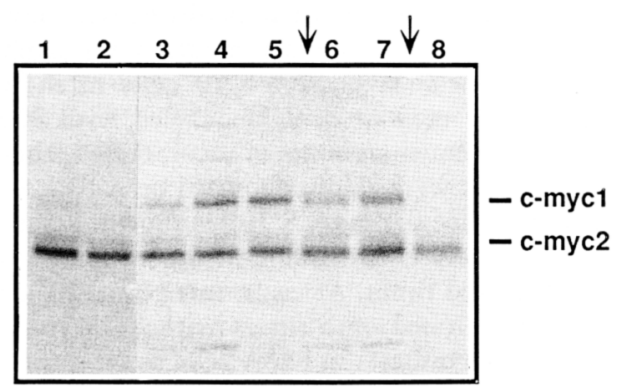

Figure 3. c-myc 1 protein synthesis in MSB-1, CEF, and MEL cells at different densities. $(A)$ MSB-l cells were grown in roller bottles as described in Fig. 2B. Cells were labeled for $20 \mathrm{~min}$ with $\left[{ }^{35} \mathrm{~S}\right]$ methionine at the following densities: (lane 1) $0.15 \times 10^{6}$; (lane 2) $0.93 \times 10^{6}$; (lane 3) $4.9 \times 10^{6}$, (lane 4) $12 \times 10^{6}$ cells $/ \mathrm{ml}$ (saturation density). The c-myc proteins were immunoprecipitated as described in Fig. 2B. (B) CEF cells were plated at $2 \times 10^{5}$ cells $/ 100-\mathrm{mm}$ dish and grown without a media change. Replicate dishes were labeled at the following densities: (lane 1) $0.2 \times 10^{6} /$ dish; (lane 2) $0.38 \times 10^{6} /$ dish; (lane 3) $24 \mathrm{hr}$ after saturation density $\left(10^{7} / \mathrm{dish}\right)$; (lane 4$) 48 \mathrm{hr}$ after saturation density. The c-myc proteins were immunoprecipitated as described in Fig. 2B. (C) MEL cells were plated at $1 \times 10^{7}$ cells $/$ $75-\mathrm{cm}^{2}$ flask in $40 \mathrm{ml}$ of DME medium supplemented with $5 \%$ FCS and $5 \%$ CS. Arrows denote when the cells were diluted $1: 1$ in fresh media. Cells $\left(10^{7}\right)$ were labeled for $20 \mathrm{~min}$ at the following times after plating: (lane 1) $24 \mathrm{hr}$; (lane 2) $25 \mathrm{hr}$; (lane 3) $36 \mathrm{hr}$; (lane 4) $48 \mathrm{hr}$; (lane 5) $72 \mathrm{hr}$; (lane 6) $96 \mathrm{hr}$; (lane 7) 120 $\mathrm{hr}$; (lane 8) $144 \mathrm{hr}$. The cells had reached saturation density $\left(8.8 \times 10^{7} \mathrm{cells} / \mathrm{flask}\right)$ after $96 \mathrm{hr}$. greater than those of c-myc 2. Similarly, there was a pronounced increase in the synthesis of $c-m y c 1$ relative to c-myc 2 as CEF cells grew to high density (Fig. 3B, lanes 3,4$)$. Finally, to determine whether the induction of c-myc 1 occurs in another species, we examined c-myc protein synthesis in MEL cells that overexpress a murine c-myc RNA from a SV40-driven c-myc cDNA (Prochownik and Kukowska 1986). Figure 3C demonstrates that c-myc 1 was induced to levels as great as those of c-myc 2 at $\sim 50 \%$ saturation density (lane 4 ). In addition, when the cells were diluted with fresh media after 96 and $120 \mathrm{hr}$ (lanes 6,8$)$ there was a significant reduction of c-myc 1 synthesis without an affect on c-myc 2 synthesis. These results suggest that the translational activation of c-myc 1 occurs in a variety of different cell types and in different species from c-myc mRNAs that have different $5^{\prime}$ structures.

\section{Conditioned/depleted media induces the synthesis of non-AUG-initiated c-myc 1}

There are several parameters associated with high-density growth inhibition that may be involved in the induction of c-myc 1 protein synthesis, such as cell-cell contact, depletion of growth factors, accumulation of growth inhibitory factors released by the cells, and/or depletion of nutrients. To determine whether any of these parameters might be involved in the induction of c-myc 1, we carried out a series of experiments using a variety of conditioned/depleted $(C D)$ media. First, to prepare the CD media, culture medium was collected every $24 \mathrm{hr}$ from Bk3A cells grown for 4 days to saturation density as described in the Materials and methods. Exponentially growing $\mathrm{Bk} 3 \mathrm{~A}$ cells were then resuspended in these different $\mathrm{CD}$ media at low density, and aliquots of the cells were harvested at 5,10 , and $24 \mathrm{hr}$ after treatment. An aliquot of the cells was also harvested before treatment $(0 \mathrm{hr})$. As shown in Figure 4A, the CD medium collected from the cells grown for 3 days ( $3 \mathrm{~d}$ medium) induced c-myc 1 synthesis 10 -fold with no change in c-myc 2 synthesis. In contrast to the 3 -day CD medium, the 1- and 2-day $C D$ media were less effective and induced c-myc 1 synthesis only after $10-24 \mathrm{hr}$ of treatment. This delay suggests that further conditioning/depleting of these media was necessary for c-myc 1 induction. Interestingly, the 4-day $\mathrm{CD}$ medium not only induced a fivefold increase in the synthesis of c-myc 1 within $5 \mathrm{hr}$, but also caused a fivefold decrease in the synthesis of c-myc 2 protein. Because of this translational switch after treatment with 4-day CD medium, the synthesis of c-myc 1 became 10 -fold higher than that of c-myc 2. Treatment with 6- to 8-day CD media resulted in a decrease in total cellular protein synthesis, including both c-myc proteins (data not shown). This inhibition of protein synthesis with this medium was most likely the result of extensive depletion of nutrients, which was also reflected by the observation of decreased cell viability. Taken together, these results suggest that the induction of c-myc 1 synthesis at high densities is dependent on the conditioning and/or depleting of the 
A
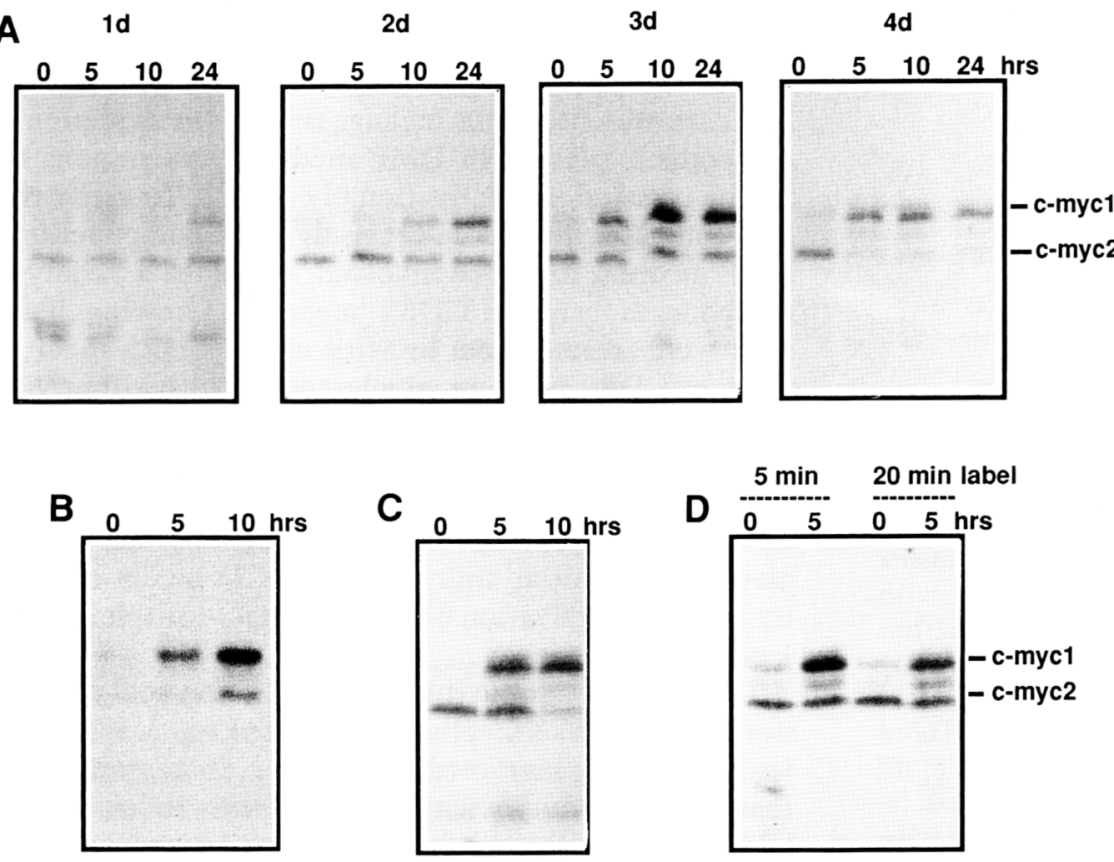

Figure 4. Effect of $C D$ media on the synthesis of $\mathrm{c}-$ myc 1 protein in growing $\mathrm{Bk} 3 \mathrm{~A}$ and MSB- 1 cells. $(A)$ Four different CD media (1- to 4-day) were collected from Bk3A cells, as detailed in the Materials and methods. The cell densities at the time of harvest were $8 \times 10^{5} \mathrm{cells} / \mathrm{ml}$ for 1 -day $\mathrm{CD}$ medium, $2.4 \times 10^{6}$ for 2-day, $8.8 \times 10^{6}$ for 3 -day, and $1.29 \times 10^{7}$ for 4-day. The different $C D$ media were then used to treat exponentially growing $\mathrm{Bk} 3 \mathrm{~A}$ cells (seeded at $10^{6} \mathrm{cell} / \mathrm{ml}$ ). Before treatment $(0 \mathrm{hr})$ and at the indicated times after treatment, $10^{7}$ cells were labeled with $\left[{ }^{35} \mathrm{~S}\right]$ methionine, and the $\mathrm{c}-\mathrm{myc}$ proteins were immunoprecipitated as described in Fig. 2B. (B) Exponentially growing MSB-1 cells $\left(5 \times 10^{5} / \mathrm{ml}\right)$ were placed into $\mathrm{CD}$ medium collected from high-density $\left(1.3 \times 10^{7} \mathrm{cells} / \mathrm{ml}\right) \mathrm{MSB}-1$ cells. Before treatment $(0 \mathrm{hr})$ and at the indicated times after treatment, $10^{7}$ cells were labeled with $\left[{ }^{35} S\right]$ methionine, and the c-myc proteins were immunoprecipitated as described in Fig. 2B. $(C)$ Exponentially growing $\mathrm{Bk} 3 \mathrm{~A}$ cells were treated with CDRS medium collected from Bk3A cells as described in the Materials and methods. Before treatment $(0 \mathrm{hr})$ and at the indicated times after treatment, $10^{7}$ cells were labeled with $\left[{ }^{35} \mathrm{~S}\right]$ methionine for $20 \mathrm{~min}$ and the c-myc proteins were immunoprecipitated as described in Fig. 2B. (D) Untreated Bk3A cells or cells treated with CDRS medium for $5 \mathrm{hr}$ as in $C$ were labeled for either 5 or 20 min with $\left[{ }^{35}\right.$ S $]$ methionine and the $\mathrm{c}-m y c$ proteins were immunoprecipitated as described in Fig. $2 \mathrm{~B}$.

growth media and not on cell-cell contact or other density-dependent parameters.

Similar to CD medium from Bk3A cells, MSB-1 4d CD medium induced a 10 -fold increase in c-myc 1 synthesis when added to exponentially growing MSB-1 cells (Fig. 4B). Unlike the Bk3A cells, however, the level of c-myc protein 2 synthesis in the MSB-1 cells was below detection before treatment. The overall higher levels of c-myc synthesis in the untreated $\mathrm{Bk} 3 \mathrm{~A}$ cells as compared with untreated MSB-1 cells may reflect the constitutively elevated levels of c-myc RNA as a result of the proviral integration at the $c-m y c$ locus. In addition, $C D$ medium from MSB-1 cells was found to be interchangeable with Bk3A CD medium in its ability to induce c-myc l synthesis in either cell type (data not shown). CDRS medium, a conditioned medium prepared by a different method as detailed in Materials and methods, was also capable of inducing a 10 -fold increase in c-myc 1 synthesis (Fig. 4C). These experiments suggest that the translational activation is not dependent on the method of $\mathrm{CD}$ media preparation.

To confirm that we were truly measuring differences in protein synthesis after treatment and not changes in protein turnover, Bk3A cells were labeled for either 5 or 20 min before and after treatment with CDRS medium for $5 \mathrm{hr}$. Figure 4D shows that no difference in the apparent level of c-myc 1 induction was observed with different labeling times, which suggests that we are evaluating synthesis and not turnover rate. Furthermore, pulse-chase analysis before and after treatment also con- firmed that there is no significant change in turnover rates of the c-myc proteins after CDRS medium treatment (data not shown).

To test directly whether growth inhibition owing to serum deprivation or physiological stress could induce c-myc 1 synthesis, Bk3A cells were first treated for up to $24 \mathrm{hr}$ with Dulbecco's modified Eagle (DME) medium, containing $0.5 \%$ calf serum (CS). Although there was a threefold increase in the synthesis of both c-myc proteins, there was no change in the ratio of $c-m y c 1$ versus 2 synthesis (Fig. 5A). Additionally, growth inhibition of MSB-1 cells or CEF cells in DME medium alone or with DME medium plus $0.5 \%$ CS also showed that c-myc 1 was not preferentially induced with serum deprivation (data not shown). Bk3A cells were then subjected to stress induced by hypertonic treatment ( $150 \mathrm{~mm}$ sucrose or $130 \mathrm{~mm} \mathrm{NaCl})$ or heat shock $\left(45^{\circ} \mathrm{C}\right)$ for 5 and $10 \mathrm{hr}$. Neither treatment resulted in a change in c-myc 1 synthesis (data not shown). Therefore, the translational activation of c-myc 1 appears to be specifically mediated by $\mathrm{CD}$ media and not as a general consequence of growth arrest or physiological stress.

To initially distinguish between the possibilities that a factor or factors had accumulated or that nutrients had been depleted from the $\mathrm{CD}$ media, Bk3A cells were treated with CDRS medium or with CDRS medium that had been diluted 50\% with fresh DME medium to replace depleted nutrients. As shown in Figure 5B, dilution with DME medium abolished the ability of the CDRS medium to induce $c-m y c 1$. Additionally, $C D$ medium 


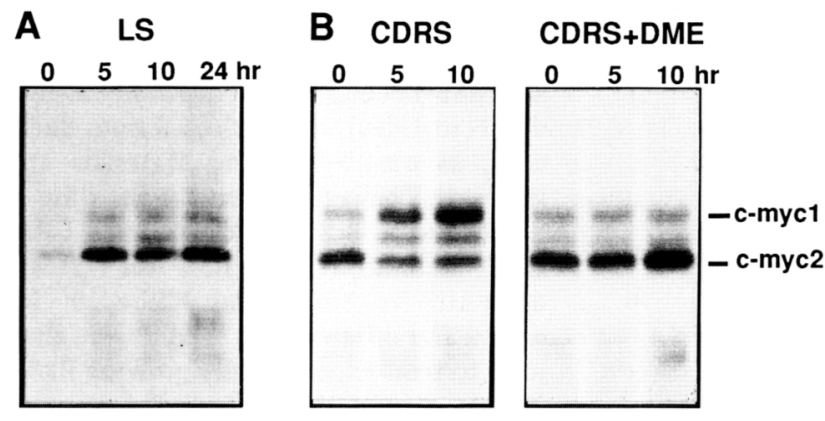

Figure 5. Effect of serum deprivation and medium addition on the synthesis of $\mathrm{c}-\mathrm{myc} 1$ protein in growing Bk3A cells. $|A|$ Exponentially growing $\mathrm{Bk} 3 \mathrm{~A}$ cells $\left(10^{6} \mathrm{cells} / \mathrm{ml}\right)$ were resuspended in DME medium containing $0.5 \%$ CS [low serum media (LS)], for the indicated times. Cells $\left(10^{7}\right)$ were labeled with $\left[{ }^{35} \mathrm{~S}\right]$ methionine for $20 \mathrm{~min}$, and the $\mathrm{c}-\mathrm{myc}$ proteins were immunoprecipitated as described in Fig. 2B. (B) Exponentially growing $\mathrm{Bk} 3 \mathrm{~A}$ cells were treated with $\mathrm{CDRS}$ medium collected from Bk3A cells or with the same CDRS medium that had been diluted $50 \%$ with fresh DME medium. Before treatment $(0 \mathrm{hr})$ and at the indicated times after treatment, $10^{7}$ cells were labeled with $\left[{ }^{35} \mathrm{~S}\right]$ methionine for $20 \mathrm{~min}$, and the $\mathrm{c}-m y c$ proteins were immunoprecipitated as described in Fig. 2B.

dialyzed (molecular mass cutoff of $5 \mathrm{kD}$ ) against fresh DME medium also suppressed the induction of c-myc 1 (data not shown). These experiments suggest that adding back a component/s/ contained in DME medium resulted in the loss of c-myc 1-inducing ability. However, to confirm that the ability to induce c-myc 1 protein synthesis was not influenced by the presence of accumulated protein factors in the conditioned/depleted media, a series of treatments were performed to remove all proteins from CDRS medium. These included trypsinization (1.5 $\mathrm{mg} / \mathrm{ml}$ for $18 \mathrm{hr}$ at $37^{\circ} \mathrm{Cl}$, heating to $100^{\circ} \mathrm{C}$ for $30 \mathrm{~min}$, and ultrafiltration (molecular mass cutoff $>0.5 \mathrm{kD}$ ). None of these treatments, singularly or combined, affected the ability of CDRS medium to induce c-myc 1 synthesis (data not shown).

\section{Amino acid deprivation induces the synthesis of $c$-myc 1 protein}

The data presented thus far suggest that the depletion of components present in DME medium was responsible for the translational activation of $c-m y c 1$. To verify this idea and determine more precisely what components of DME medium might be involved, we added a variety of components back to CDRS medium. Growing Bk3A cells were treated for $5 \mathrm{hr}$ with either CDRS medium alone or CDRS medium supplemented with either vitamins, Earle's salts, essential amino acids (EAA), or nonessential amino acids (NEAA). As shown in Figure 6A, only the addition of EAA (lane 4) suppressed the synthesis of c-myc 1 protein. This result suggests that the depletion of essential amino acids in $C D$ media leads to translational activation of the non-AUG-initiated c-myc 1 protein.

To directly examine the effects of amino acid deprivation, growing Bk3A cells were treated for 5 and $10 \mathrm{hr}$ with EAA-deficient medium. Figure $6 \mathrm{~B}$ demonstrates that deprivation of essential amino acids induced a 10fold increase in the synthesis of c-myc 1 protein synthesis, comparable to the effects of CDRS medium. Addition of $10 \%$ dialyzed calf serum (DCS) to EAA-deficient medium had no effect on the induction of c-myc 1 synthesis, again suggesting that the presence or absence of growth factors has no influence on c-myc 1 translational activation. CEF cells were also treated with EAA-deficient medium to determine whether this treatment had a similar effect on c-myc 1 synthesis in normal fibroblasts. As shown in Figure 6C, there was a dramatic increase in c-myc 1 protein synthesis within $5 \mathrm{hr}$. Similar to untreated MSB-1 cells (Fig. 4B), the levels of c-myc 2 synthesis in the untreated CEF cells were below detectable levels.

Our results have demonstrated that the translational activation of $\mathrm{c}-\mathrm{myc} \mathrm{l}$ is induced by the deprivation of all essential amino acids. As an initial test to determine whether the deprivation of a single essential amino acid can induce c-myc 1 protein, Bk3A cells were treated for
A

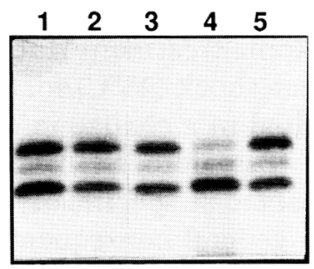

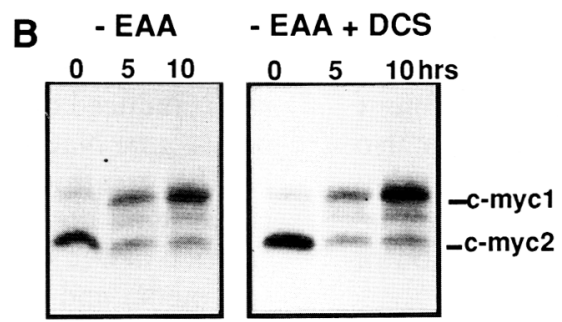

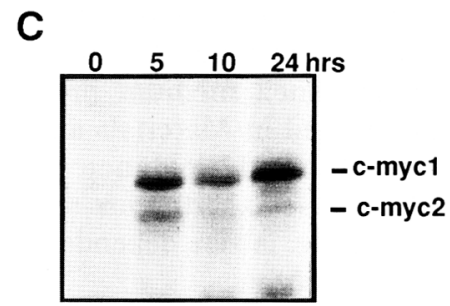

Figure 6. Effect of essential amino acid deprivation on the synthesis of c-myc 1 in growing Bk3A and secondary CEF cells. $(A)$ Exponentially growing Bk3A cells $\left(10^{6}\right.$ cells $\left./ \mathrm{ml}\right)$ were treated for $5 \mathrm{hr}$ with CDRS medium collected from Bk3A cells (lane 1) or the same CDRS medium supplemented with MEM vitamins (lane 2), Earle's salts (lane 3), MEM essential amino acids (lane 4), or MEM nonessential amino acids (lane 5). Cells $\left(10^{7}\right)$ were labeled with $\left[{ }^{35} \mathrm{~S}\right]$ methionine for $20 \mathrm{~min}$, and the c-myc proteins were immunoprecipitated as described in Fig. 2B. $(B)$ Growing Bk3A cells were treated with EAA-deficient medium or EAA-deficient medium supplemented with $10 \%$ DCS. Before treatment $\mid 0 \mathrm{hr}$ ) and at the indicated times after treatment, $10^{7}$ cells were labeled with $\left[{ }^{35} \mathrm{~S}\right]$ methionine for $20 \mathrm{~min}$, and the c-myc proteins were immunoprecipitated as described in Fig. $2 \mathrm{~B}$. $(\mathrm{C}) \mathrm{Growing} \mathrm{CEF}$ cells $\left(10^{6}\right.$ cells $/ 100-\mathrm{mm}$ dish) were treated with EAA- deficient medium for the indicated times. Each dish of cells was labeled with $\left[{ }^{35} \mathrm{~S}\right] \mathrm{me}-$ thionine for $20 \mathrm{~min}$, and the c-myc proteins were immunoprecipitated as described in Fig. $2 \mathrm{~B}$. 
24 hr with EAA-deficient medium, EAA-supplemented medium, or medium lacking only one of the essential amino acids, such as leucine, isoleucine, methionine, or tyrosine. As shown in Figure 7A (lane 1), EAA-deficient medium induced the synthesis of $\mathrm{c}-\mathrm{myc} 1$. We also observed a substantial increase in the levels of the two additional c-myc proteins of $60 \mathrm{kD}$ and $62 \mathrm{kD}$. These alternative forms were normally present in much lower levels. Addition of the essential amino acids to the EAAdeficient medium suppressed the induction of $\mathrm{c}-m y c 1$ (lane 2) and the additional forms of c-myc. The only other treatment that resulted in the induction of c-myc 1 other than EAA-deficient medium was the deprivation for methionine alone (lane 3). Deprivation of other essential amino acids had no effect on c-myc 1 synthesis (lanes 4-6). Deprivation of cysteine also did not induce synthesis of c-myc 1 (data not shown). Again, the induction of $c-m y c 1$ was not a result of growth inhibition, because deprivation of any of these essential amino acids inhibited cell proliferation (data not shown). Taken together, these data suggest that reduced methionine availability alone is responsible for the translational activation of c-myc 1 .

As a final examination of the effects of methionine deprivation on $\mathrm{c}-m y c 1$ translational activation, we treated growing Bk3A cells for 5 and $10 \mathrm{hr}$ with CDRS medium, EAA-deficient medium, methionine-deficient medium, or DME medium, all of which were supplemented with $5 \%$ DCS. As shown in Figure 7B, all of the treatments, except the DME medium plus $5 \%$ DCS, caused a 6- to 9-fold induction of $c-m y c 1$ with either no change or a decrease in c-myc 2 synthesis. Also, the same results were obtained when $\mathrm{Bk} 3 \mathrm{~A}$ cells were labeled with either $\left[{ }^{35} \mathrm{~S}\right]$ methionine or $\left[{ }^{35} \mathrm{~S}\right]$ cysteine (data not shown). Replacement of the growth medium with fresh DME medium plus $5 \%$ DCS failed to induce preferential c-myc 1 synthesis but did induce a threefold increase in total $c-m y c$ protein synthesis. This increase in total c-myc protein synthesis was seen previously with DME medium with low serum $(0.5 \% \mathrm{CS})$ (Fig. 5A) and also occurs with fresh DME medium without CS /data not shown). Finally, to confirm that methionine deprivation alone was responsible for the ability of EAA-deficient medium to induce c-myc l, growing Bk3A cells were treated with EAA-deficient medium or EAA-deficient medium to which only methionine was added. Figure $7 \mathrm{C}$ demonstrates that the deprivation of all the essential amino acids causes the induction of c-myc 1, whereas deprivation of all the essential amino acids except methionine had no effect. Taken together, these results suggest that the translational activation of the non-AUGinitiated c-myc 1 protein observed at high cell densities and after treatment with CD media is specifically mediated by methionine availability.

\section{Discussion}

Our results describe a specific and dramatic regulation of dual translational initiation in vertebrate cells. We have demonstrated that as a variety of cell types approach
A
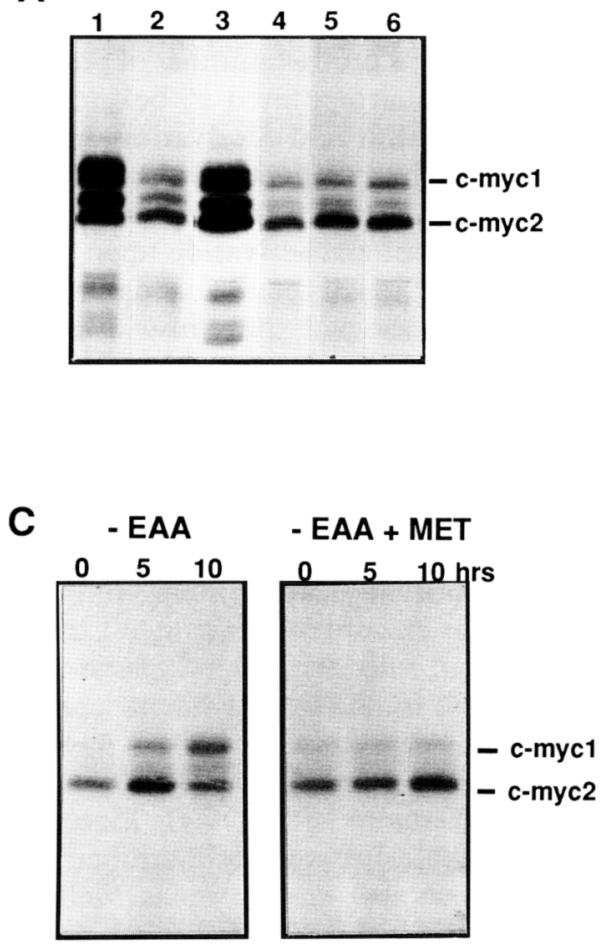

B

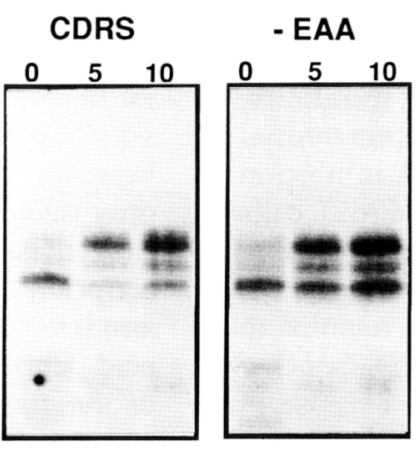

Figure 7. Effect of specific amino acid deprivation on the synthesis of c-myc 1 protein in Bk3A cells. $(A)$ Exponentially growing Bk3A cells $\left(10^{6}\right.$ cells $\left./ \mathrm{ml}\right)$ were treated for $24 \mathrm{hr}$ with EAA-deficient medium (lane 1), EAA-deficient medium with MEM EAAs added (lane 2), methionine-deficient medium (lane 3), isoleucine-deficient medium (lane 4), leucine-deficient medium (lane 5), or tyrosine-deficient medium (lane 6). Cells $\left(10^{7}\right)$ were labeled with $\left.{ }^{35} \mathrm{~S}\right]$ methionine for $20 \mathrm{~min}$, and the c-myc proteins were immunoprecipitated as described in Fig. 2B. $(B)$ Growing Bk3A cells were treated with CDRS medium collected from Bk3A cells supplemented with $5 \%$ DCS, EAA-deficient medium plus $5 \%$ DCS, methionine-deficient medium plus $5 \%$ DCS, or DME medium plus $5 \%$ DCS. Before treatment $(0 \mathrm{hr})$ and at the indicated times after treatment, $10^{7}$ cells were labeled with $\left[{ }^{35} \mathrm{~S}\right]$ methionine for 20 min, and the c-myc proteins were immunoprecipitated as described in Fig. 2B. $|C|$ Growing Bk3A cells were treated with EAA-deficient medium or EAA-deficient medium supplemented with methionine. Before treatment $(0 \mathrm{hr})$ and at the indicated times after treatment, $10^{7}$ cells were labeled with $\left[{ }^{35} \mathrm{~S}\right]$ methionine for $20 \mathrm{~min}$ and the c-myc proteins were immunoprecipitated as described in Fig. 2B. 
saturation density, there is a sustained 5- to 10-fold induction of the non-AUG-initiated c-myc 1 protein synthesis from a single mRNA. Treatment with CD media from high-density cells was able to reproduce the activation of c-myc 1 protein synthesis in low-density cells within $5 \mathrm{hr}$. In contrast, the synthesis of the AUG-initiated c-myc 2 protein was minimally affected or was significantly suppressed, depending on the treatment. Further analysis of the c-myc 1-inducing ability of CD media revealed that methionine deprivation was responsible for this unusual regulation. Interestingly, depletion of methionine in these cells resulted in an increase in non-AUG-initiated synthesis of c-myc without significantly affecting overall protein synthesis. Levinson et al. (1980) also found that methionine deprivation of CEF cells had minimal effects on overall protein synthesis. In contrast, Scorsone et al. (1987) reported that there was a dramatic and rapid effect on total protein synthesis upon glutamine starvation of Ehrlich cells (Scorsone et al. 1987), suggesting that the effects of amino acid deprivation on total protein synthesis may be dependent on the specific amino acid or on the cell type. Taken together, our data suggest that the induction of c-myc 1 synthesis appears to be in response to a reduction of methionine availability below a certain intracellular threshold and not as a result of severe depletion because synthesis of total cellular proteins and of another proto-oncogene, $\mathrm{c}-\mathrm{my} b$, is not significantly affected.

The translational activation of c-myc 1 appears to be specific for growth inhibition mediated by methionine deprivation rather than a general consequence of growth inhibition or physiological stress, because growth inhibition owing to deprivation of other essential amino acids or serum factors had no effect on the induction of c-myc 1 synthesis. In further support of this specificity, we have shown previously that there was no preferential increase in c-myc 1 synthesis during growth inhibition associated with the terminal differentiation of MEL cells (Spotts and Hann 1990). There is, however, a translational activation of c-myc 1 in MEL cells owing to depletion of the media at high cell densities. It remains to be seen whether c-mycl is induced similarly in other types of cells upon methionine deprivation. Because of differing growth requirements, some cells may vary in their response to amino acid deprivation, and, therefore, the kinetics and/or magnitude of c-myc 1 translational activation may also vary.

In addition to a change in codon selection, we have often observed an overall increase in total c-myc protein synthesis, such as after serum deprivation of Bk3A cells. One possible explanation for this increase is enhanced translation. Enhanced translation of c-myc protein from relatively low levels of c-myc RNA has been observed in Bk3A cells at high density (K. Sloan-Brown and S.R. Hann, unpubl.) and in differentiating MEL cells (Spotts and Hann 1990). The substantial increase in c-myc protein synthesis in CEF and MSB-1 cells upon amino acid deprivation or after treatment with $\mathrm{CD}$ medium, however, suggests that there may also be transcriptional in- creases of c-myc under some deprivation conditions. Pohjanpelto and Holtta (1990) have observed an increase in c-myc mRNA levels between 2 and $12 \mathrm{hr}$ following deprivation of any one of several essential amino acids in Chinese hamster ovary cells. Further studies will be necessary to determine the influences of transcriptional increases and enhanced translation on the overall levels of c-myc protein synthesis upon methionine deprivation. Nonetheless, the translational activation of c-myc 1 appears to be independent of changes in c-myc RNA levels and overall translational efficiency of the c-myc transcripts.

\section{Translational regulation in response to amino acid deprivation}

In yeast there is a well-studied example of translational activation mediated by amino acid deprivation. It has been shown that upon starvation of any single essential amino acid in Saccharomyces cerevisiae, the translation of the transcription factor GCN4 is dramatically increased. GCN4 plays an essential role in amino acid metabolism and is translationally induced through a complex mechanism involving the inhibition of reinitiation of translation of one of the small upstream open reading frames (Abastado et al. 1991). Unlike in yeast, there have been few studies in higher eukaryotes on the effects of amino acid deprivation on the translation of specific cellular mRNAs. A study that examined the effects of methionine deprivation on protein synthesis in CEF cells reported no effect on either the pattern of cellular proteins as resolved by one-dimensional gel electrophoresis or on the rate of overall protein synthesis (Levinson et al. 1980). Other investigators examined the effects of amino acid starvation on the expression of specific proteins in rat hepatoma cells by two-dimensional gel electrophoresis (Shay et al. 1990). Only a limited number of proteins, however, were detected that appeared to be increased only twofold following amino acid deprivation. In addition, these changes may have reflected increased transcription. Therefore, before this study, there were no examples of a specific translational activation upon amino acid deprivation in higher eukaryotes. Our observation of the translational activation of the c-myc 1 protein suggests that higher eukaryotes do indeed have specific translational responses to amino acid deprivation.

On the basis of our findings, it is reasonable to postulate that higher eukaryotic cells have the ability to rapidly modulate the levels of other proteins in response to environmental changes by increasing the efficiency of their normally suboptimal translational initiation. There are several recent examples of inefficient translational initiation that fall into two general classes. Both classes are comprised of important regulatory proteins. One class of proteins, exemplified by c-myc 1 , which initiate inefficiently from non-AUG codons, includes transcription factors (Lemaire et al. 1990; Xiao et al. 1991), a growth factor (Florkiewicz and Sommer 1989; Prats et al. 1989), and several proto-oncogenes (Mellentin et al. 1989; Acland et al. 1990; Lock et al. 1991; Saris et 
al. 1991). The other class of proteins are inefficiently translated because of inhibitory elements upstream of their AUG start codon. For example, the removal of inhibiting upstream AUGs from the mRNA of the protooncogene Ick (Marth et al. 1988) or upstream secondary structure from the c-sis/PDGF mRNA (Rao et al. 1988) has been reported to result in increased translational efficiency. Our finding that $c-m y c 1$ protein can be translationally activated upon methionine deprivation suggests that these two classes of regulatory proteins may also be translationally activated during specific growth phases or in response to environmental conditions. These environmental conditions, however, may not necessarily be methionine deprivation as for c-myc 1 .

\section{Possible mechanisms for the translational activation of a non-AUG-initiated protein}

Our results raise the question as to how methionine deprivation modulates the translational machinery to allow preferential initiation from the non-AUG codon rather than from the AUG codon. Kozak's scanning model predicts that a $43 \mathrm{~S}$ preinitiation complex, consisting of the $40 S$ ribosomal subunit, Met-tRNA Met , GTP, and the initiation factors eIF-2 and eIF-3, binds to the $5^{\prime}$ end of the mRNA and then migrates 3 ' until the complex encounters the first initiation codon (Kozak 1989b; Hershey 1991). Other than the exceptions that we have discussed, this site is nearly always the first AUG. The sequence surrounding the initiator codon and the secondary structure of the mRNA are critical for proper recognition of the start codon and influence the efficiency of translation initiation (Pelletier and Sonenberg 1986; Kozak $1989 \mathrm{~b}, \mathrm{c})$.

It is less understood, however, how the scanning complex recognizes a non-AUG codon. The efficiency of translation has been found to vary among the different non-AUG codons (Kozak 1989a; Peabody 1989). Also, thus far, only CUG, ACG, and AUU have been found as non-AUG initiator codons of transcripts in higher eukaryotes (Kozak 1991). Therefore, the scanning complex appears to recognize the different non-AUG codons with different efficiencies. Because the Met-tRNA ${ }_{i}^{\text {Met }}$ is used to initiate translation at both an AUG and non-AUG codon, there is a partial mismatch between the nonAUG codon and the anticodon (Donahue et al. 1988; Peabody 1989|. Because of this partial mismatch, the sequence context and secondary structure of the mRNA has been shown to be even more critical for non-AUG codon recognition (Kozak 1989b). Using synthetic constructs, Kozak has suggested that the presence of a hairpin loop 14 bp downstream of a non-AUG initiator codon enhances non-AUG initiation by slowing the scanning process of the preinitiation complex over the non-AUG codon (Kozak 1990). Most of the mRNAs that can initiate at a non-AUG, such as c-myc, basic fibroblast growth factor, int-2, pim-1, and Krox 24 have the potential to form such a downstream loop structure (Kozak 1990; 1991).

Although initiation at a non-AUG codon can be opti- mized for sequence and secondary structure, a non-AUG is still less efficient than an AUG at the same location (Kozak 1989a; Peabody 1989). Thus, the question still persists as to how methionine deprivation causes an increase in the translational efficiency at a non-AUG initiator codon. There are several theoretical answers to this question. The model that we favor proposes that an alteration of components in the scanning preinitiation complex occurs that directly effects start codon selection (Fig. 8). A key initiation factor that is required for formation of the complex and its ability to recognize the start codon is eIF-2 (Hershey 1991). The idea that eIF-2 may be directly involved in start codon selection and the translational activation of $c-m y c 1$ is supported by the findings that mutations in the $\alpha$ or $\beta$ subunit of eIF- 2 allow initiation at a non-AUG (UUG) codon of a mutant HIS4 gene in yeast (Donahue et al. 1988). Also, mutations in either the $\alpha$ or $\beta$ subunits of eIF- 2 lead to constitutive activation of GCN4 independent of amino acid starvation (Williams et al. 1989). Recently, Dever et al. (1992) have shown that the amino acid starvation-induced translational activation of GCN4 is mediated by the phosphorylation of eIF- $2 \alpha$.

Phosphorylation of eIF-2 subunits is also a well-described mechanism for down-regulating eIF-2 activity and inhibiting overall initiation of protein synthesis in higher eukaryotic cells (Hershey 1991). Amino acid deprivation has been shown to inhibit total protein synthesis and increase phosphorylation of eIF- $2 \alpha$ in Ehrlich cells (Scorsone et al. 1987). Because total protein synthesis was not significantly affected in our experiments, however, methionine deprivation may influence the phosphorylation state of the eIF-2 subunits differently from deprivation of other amino acids. Variations in the phosphorylation status of eIF-2 subunits in eukaryotic cells may influence codon selection during the scanning of the preinitiation complex, perhaps by stabilizing the partially mismatched codon-anticodon interaction. These phosphorylation changes in eIF-2 subunits may be induced by methionine deprivation through the deacylation of Met-tRNA $A_{i}^{\text {Met }}$ and/or the elevation of methionyl tRNA synthetase levels. These events have been reported to be some of the earliest eukaryotic cellular responses to methionine deprivation (Lazard et al. 1987). Interestingly, an aminoacyl-tRNA synthetase-associated kinase has been identified in yeast that enhances GCN4 translation upon amino acid deprivation by phosphorylating eIF-2 $\alpha$ (Wek et al. 1989, Ramirez et al. 1991; Dever et al. 1992). Therefore, an aminoacyl-tRNA synthetase-associated kinase may exist in higher eukaryotes that may be modulated by levels of uncharged methionyl tRNAs.

This model does not exclude the possibility that a slowing of the scanning process by downstream secondary structure may also be necessary (Fig. 8). This slowing, or stalling, of the preinitiation complex over the non-AUG codon would enhance the stabilization of the partially mismatched codon-anticodon interaction and thus increase non-AUG initiation. The increase in nonAUG initiation may also involve a change in the ability 
Figure 8. Model for the translational activation of $\mathrm{c}-\mathrm{myc} 1$ protein. $(A)$ In growing cells the scanning preinitiation complex containing the $40 \mathrm{~S}$ ribosomal subunit, Met-tRNA ${ }_{i}^{\text {Met }}$, eIF-2, and a helicase activity migrates $5^{\prime} \rightarrow 3^{\prime}$, melting secondary structure, until the first AUG is encountered. Upon AUG recognition involving codon-anticodon interaction, the $60 \mathrm{~S}$ ri- $^{-}$ bosomal subunit binds to the preinitiation complex and translation initiates. $(B) \mathrm{Me}$ thionine deprivation induces a change in subunits of eIF-2 involved in codon selection. This change stabilizes the partial mismatch with the non-AUG codon. The downstream hairpin loop and a putative helicase activity in the complex may or may not have roles in this regulation.
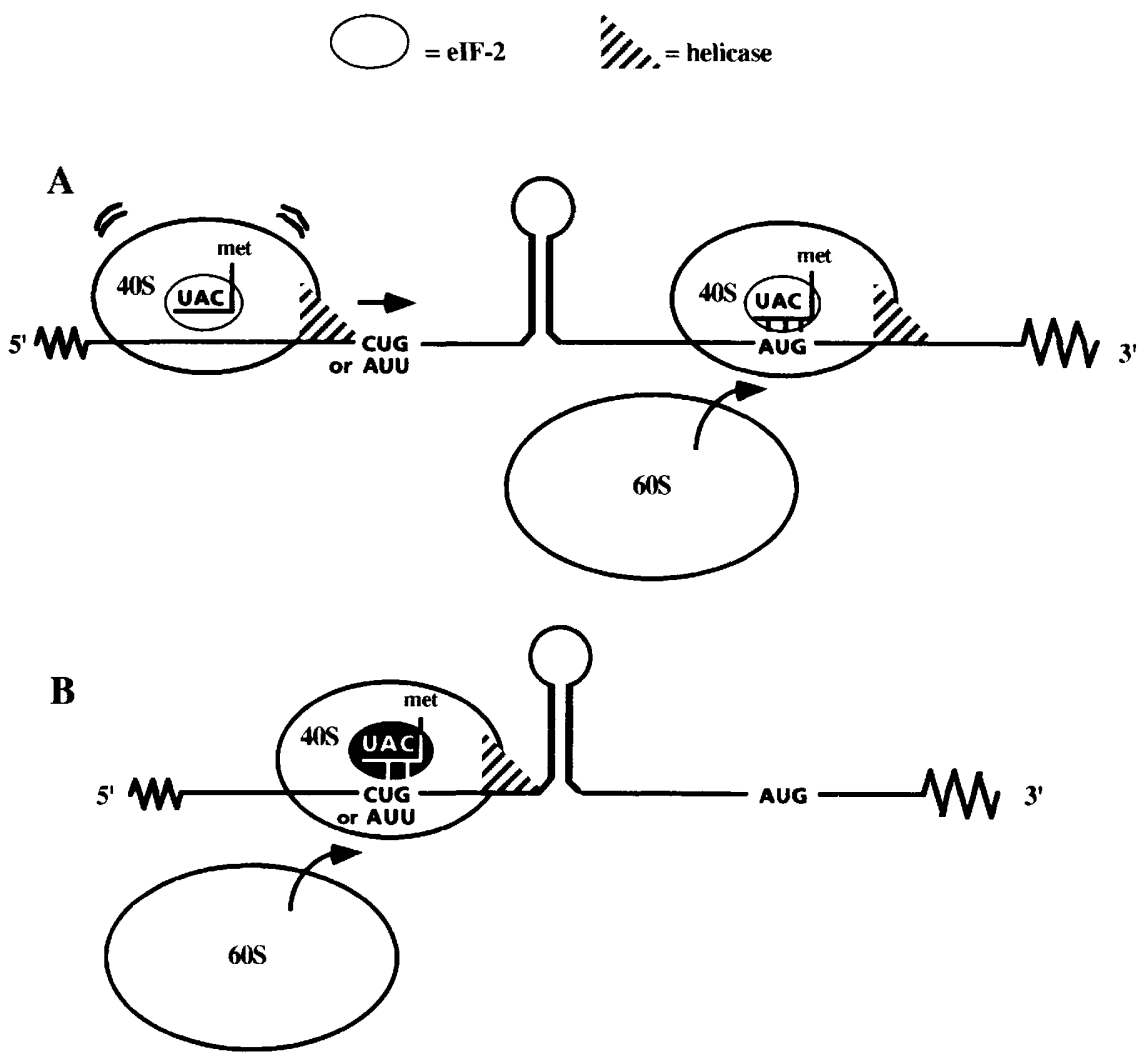

of the scanning complex to melt a hairpin loop through either a stabilization of the secondary structure or an alteration in the ability of the scanning preinitiation complex to unwind the downstream secondary structure through inactivation of a helicase.

\section{Implications for the function of $c$-myc 1}

The dramatic and specific translational activation of c-myc 1 in response to methionine availability suggests a functional significance for this regulation. The only other known translational activation in response to amino acid starvation in eukaryotes is that of the transcriptional activator GCN4 as a mechanism to regulate the biosynthesis of amino acids in yeast. Interestingly, GCN4 and c-myc are members of a family of transcription factors that share a leucine zipper motif that is necessary for dimerization and essential for DNA binding (Landschulz et al. 1988). Although higher eukaryotic cells do not synthesize essential amino acids de novo, there would still appear to be a need to translationally activate potentially important regulatory proteins such as c-myc 1 to modulate cellular functions in response to limiting nutrients.

The induction of c-myc 1 synthesis as cells approach high-density growth inhibition suggests that this translational activation may be a signal for the cell to slow or inhibit cell growth under adverse conditions. This idea, however, is in direct conflict with the idea that c-myc is associated with growth stimulation. One possible expla- nation could be that the c-myc 2 protein, which is the predominant $c-m y c$ protein synthesized in growing cells and is often translationally repressed during methionine deprivation, may mediate the signal for growth stimulation. Therefore, the two c-myc proteins would have opposing functions. The idea that c-myc 1 may inhibit cellular proliferation is supported by our previous findings that $\mathrm{c}-\mathrm{myc} 1$ is absent in tumor cell lines that have an altered c-myc gene such as human Burkitt's lymphomas (Hann et al. 1984, 1988). The inactivation of c-myc 1 synthesis may therefore give a selective growth advantage to these tumor cells. As an extension of this idea, perhaps these tumors have thus lost the ability to modulate growth under adverse conditions such as limiting nutrients and therefore continue to grow uncontrolled until necrosis occurs due to severe nutrient loss.

\section{Materials and methods}

Cell lines

The avian bursal lymphoma cell line, Bk3A, obtained from $M$. Linial (Hutchinson Cancer Center, Seattle, WA), and the MSB-1 cells, a Marek's virus-transformed chicken thymocyte line, obtained from C. Thompson (University of Michigan, Ann Arbor), have been described previously (Hihara 1974; Schubach and Groudine 1984). Bk3A and MSB-1 cells were cultured in suspension cell media (SCM) consisting of DME medium (GIBCO), supplemented with $10 \%$ tryptose phosphate, 5\% CS (Definedsupplemented, Hyclone Laboratories), 1\% heat-inactivated chick serum (GIBCO), and $1000 \mathrm{U} / \mathrm{ml} 1: 1$ penicillin/strepto- 
mycin and maintained at $37^{\circ} \mathrm{C}$ in humidified $5 \% \mathrm{CO}_{2}$ atmosphere. Secondary CEFs (white leghorn embryos) were obtained from L. Sealy (Vanderbilt University, Nashville, TN) and maintained in F-10 medium (GIBCO) supplemented as above. MEL cells were obtained from E. Prochownik (University of Michigan, Ann Arbor).

\section{Media preparation}

$C D$ media were prepared by two methods. The first type of $C D$ media were prepared by seeding Bk3A or MSB-1 cells in $400 \mathrm{ml}$ of $\mathrm{SCM}$ at $2.5 \times 10^{5}$ cells $/ \mathrm{ml}$ in roller bottles. The media were harvested after 4 days, unless indicated otherwise, by centrifugation of the cells at $1000 \mathrm{~g}$ for $5 \mathrm{~min}$, followed by clarification at $10,000 \mathrm{~g}$ for $10 \mathrm{~min}$. The second type of conditioned medium (CDRS) was prepared by resuspending the cells that were grown for 4 days into $200 \mathrm{ml}$ of DME medium supplemented with $10 \%$ controlled processed serum replacement (CPSR-2, Sigma) and culturing in a roller bottle for another $24 \mathrm{hr}$. A serum replacement was needed during the conditioning period to maintain cell viability. The medium was then harvested as described above. Essential amino acid-deficient medium and specific amino acid-deficient media were prepared from Select-Amine kits (GIBCO) or were purchased ready-made (GIBCO) and were supplemented with $1 \mathrm{gram} /$ liter of glucose, glutamine, MEM nonessential amino acids (GIBCO), and 5-10\% DCS (GIBCO) unless specified otherwise. All media were adjusted to $\mathrm{pH} 7.2$.

\section{Preparation of c-myc antisera}

An affinity-purified rabbit avian-specific c-myc peptide antibody (anti-av-myc 12C) was generated as described previously (Hann et al. 1983). Briefly, a New Zealand white rabbit was inoculated with complete Freund's adjuvant containing $500 \mu \mathrm{g}$ of avian of c-myc carboxy-terminal peptide (12-mer) conjugated to bovine serum albumin (BSA). The antiserum was affinity purified by sequential chromatography on protein A-Sepharose, BSA-conjugated Sepharose (to remove antibodies to BSA) and, finally, c-myc peptide-conjugated Sepharose. Identical immunoprecipitation results were obtained with another avian-specific antiserum (anti-avian c-myc serum), which was generated by inoculation of a New Zealand white rabbit with complete Freund's adjuvant containing $500 \mu \mathrm{g}$ of a bacterially expressed fusion protein (TrpE protein fused to the carboxy-terminal half of $\mathrm{v}-\mathrm{myc}$ ). The fusion protein was purified by insoluble fractionation and SDS-gel purification prior to inoculation.

\section{Immunoprecipitation}

Cell samples were collected $\left(1 \times 10^{7}\right.$ cells $)$ at various times (hours) as indicated in the figures, washed twice with PBS, and labeled with $250-350 \mu \mathrm{Ci}$ of $\left[{ }^{35} \mathrm{~S}\right]$ methionine in $1 \mathrm{ml}$ of methionine-free medium (GIBCO) for $20 \mathrm{~min}$ at $37^{\circ} \mathrm{C}$. Cells were then washed once with PBS and stored at $-80^{\circ} \mathrm{C}$ until preparation for immunoprecipitation. Radiolabeled cells were solubilized in cold Ab buffer (Spotts and Hann 1990) containing $10 \mathrm{~mm}$ iodoacetamide and disrupted by sonication at $4^{\circ} \mathrm{C}$. The amount of $\left[{ }^{35} \mathrm{~S}\right]$ methionine incorporated into cellular proteins was determined by precipitation onto filters with $10 \%$ TCA. Equivalent amounts of TCA-precipitable counts from each cellular lysate were adjusted to equal volumes with $\mathrm{Ab}$ buffer and precleared by incubation with Staphylococcus aureus membranes (Immuno-Precipitin, BRL) and centrifugation (10 $\mathrm{min}$ at $10,000 \mathrm{~g}$ ) before addition of antisera. c-myc proteins were immunoprecipitated by the addition of $5 \mu \mathrm{g}$ of anti-av-myc $12 \mathrm{C}$ antibody or 5 $\mu l$ of anti-avian myc serum. Immune complexes were precipi- tated at $4^{\circ} \mathrm{C}$ with Immuno-Precipitin for $30 \mathrm{~min}$. The immunoprecipitation complexes were washed three times with $4^{\circ} \mathrm{C}$ RIPA buffer (Spotts and Hann 1990) and incubated at $95^{\circ} \mathrm{C}$ for 3 min in $1 \times$ Laemmli sample buffer. Samples were subjected to SDS-PAGE ( $10 \%$ acrylamide) and fluorographed as described by Skinner and Griswold (1983). Relative levels of c-myc 1 and 2 were determined by densitometric analysis on an LKB densitometer. High-range protein molecular weight markers (BRL) were used as standards in each SDS-PAGE and visualized by staining with Coomassie brilliant blue. Molecular mass standards consisted of phosphorylase B, 97,400 daltons; BSE, 68,400 daltons; and ovalbumin, 43,000 daltons.

\section{Acknowledgments}

We thank Suzanne Justis for assistance with the photography and Elizabeth Wolf for assistance with manuscript preparation. We also thank Marilyn Kozak, Thomas Donahue, Gail Cornwall, Tom Daniel, Doug Cavener, Curt Hagedorn, Jeff Holt, and Ed Leof for critical review of this manuscript. This work was supported by U.S. Public Health Service grants CA-47399 and CA-48799 from the National Cancer Institute and by a grant from the Life and Health Insurance Medical Research Fund.

The publication costs of this article were defrayed in part by payment of page charges. This article must therefore be hereby marked "advertisement" in accordance with 18 USC section 1734 solely to indicate this fact.

\section{References}

Abastado, J., P.F. Miller, and A.G. Hinnebusch. 1991. A quantitative model for translational control of the GCN4 gene of Saccharomyces cerevisiae. New Biol. 3: 51 1-524.

Acland, P., M. Dixon, G. Peters, and C. Dickson. 1990. Subcellular fate of the Int-2 oncoprotein is determined by choice of initiation codon. Nature 343: 662-665.

Dever, T.E., L. Feng, R.C. Wek, A.M. Cigan, T.F. Donahue, and A.G. Hinnebusch. 1992. Phosphorylation of initiation factor $2 \alpha$ by protein kinase GCN2 mediates gene-specific translational control of GCN4 in yeast. Cell 68: 585-596.

Donahue, T.F., A.M. Cigan, E.K. Pabich, and B.C. Valavicius. 1988. Mutations at a $\mathrm{Zn}(\mathrm{II})$ finger motif in the yeast elF-2 $\beta$ gene alter ribosomal start-site selection during the scanning process. Cell 54: 621-632.

Florkiewicz, R.Z. and A. Sommer. 1989. Human basic fibroblast growth factor gene encodes four polypeptides: Three initiate translation from non-AUG codons. Proc. Natl. Acad. Sci. 86: 3978-3981.

Hann, S.R. and R.N. Eisenman. 1984. Proteins encoded by the human c-myc oncogene: Differential expression in neoplastic cells. Mol. Cell. Biol. 4: 2486-2497.

Hann, S.R., H.D. Abrams, L.R. Rohrschneider, and R.N. Eisenman. 1983. Proteins encoded by v-myc and c-myc oncogenes: Identification and localization in acute leukemia virus transformants and Bursal lymphoma cell lines. Cell 34: 789-798.

Hann, S.R., M.W. King, D.L. Bentley, C.W. Anderson, and R.N. Eisenman. 1988. A non-AUG translational initiation in c-myc exon 1 generates an $\mathrm{N}$-terminally distinct protein whose synthesis is disrupted in Burkitt's lymphomas. Cell 52: 185-195.

Hann, S.R., C.B. Thompson, and R.N. Eisenman. 1985. c-myc oncogene protein synthesis is independent of the cell cycle in human and avian cells. Nature 314: 366-369.

Hershey, J.W.B. 1991. Translational control in mammalian cells. Annu. Rev. Biochem. 60: 717-755. 
Hihara, H., T. Shimizu, and M. Yamamoto. 1974. Establishment of tumor cells cultured from chickens with avian lymphoid leukosis. Natl. Inst. Animal Health Quart. 14: 163173.

Kozak, M. 1989a. Context effects and inefficient initiation at non-AUG codons in eukaryotic cell-free translation systems. Mol. Cell. Biol. 9: 5073-5080.

1989b. The scanning model for translation: An update. I. Biol. Chem. 108: 229-241.

1989c. Circumstances and mechanisms of inhibition of translation by secondary structures in eukaryotic mRNAs. Mol Cell. Biol. 9: 5134-5142.

- 1990. Downstream secondary structure facilitates recognition of initiator codons by eukaryotic ribosomes. Proc. NatI. Acad. Sci. 87: 8301-8305.

- 1991. Structural features in eukaryotic mRNAs that modulate the initiation of translation. 1. Biol. Chem. 266: $19867-19870$.

Landschulz, W.H., P.F. Johnson, and S.L. McKnight. 1988. The leucine zipper: A hypothetical structure common to a new class of DNA binding proteins. Science 240: 1759-1764.

Lazard, M., M. Mirande, and J. Waller. 1987. Expression of the aminoacyl-tRNA synthetase complex in cultured Chinese hamster ovary cells. I. Biol. Chem. 262: 3982-3987.

Lemaire, P., C. Vesque, J. Schmitt, H. Stunnenberg, R. Frank, and P. Charnay. 1990. The serum-inducible mouse gene Krox-24 encodes a sequence specific transcriptional activator. Mol. Cell. Biol. 10: 3456-3467.

Levinson, W., S. Kravitz, and J. Jackson. 1980. Amino acid deprivation induces synthesis of four proteins in chick embryo cells. Exp. Cell. Res. 130: 459-463.

Linial, M., N. Gunderson, and M. Groudine. 1985. Enhanced transcription of c-myc in bursal lymphoma cells requires continuous protein synthesis. Science 230: 1126-1132.

Lock, P., S. Ralph, E. Stanley, I. Boulet, R. Ramsay, and A.R. Dunn. 1991. Two isoforms of murine hck, generated by utilization of alternative translational initiation codons, exhibit different patterns of subcellular localizations. Mol. Cell. Biol. 11: 4363-4370.

Lüscher, B. and R.N. Eisenman. 1990. New light on myc and myb. Part I. Myc. Genes \& Dev. 4: 2925-2035.

Marth, J.D., R.W. Overell, K.E. Meier, E.D. Krebs, and R.M. Perlmutter. 1988. Translational activation of the $1 c k$ protooncogene. Nature 332: 171-173.

Mellentin, J.D., S.D. Smith, and M.L. Cleary. 1989. lyl-1, a novel gene altered by chromosomal translocation in $\mathrm{T}$ cell leukemia, codes for a protein with a helix-loop-helix DNA binding motif. Cell 58: 77-83.

Nottenburg, C. and H.E. Varmus. 1986. Features of the chicken c-myc gene that influence the structure of c-myc RNA in normal cells and Bursal lymphomas. Mol. Cell. Biol. 6: $2800-2806$.

Peabody, D.S. 1989. Translation initiation at non-AUG triplets in mammalian cells. J. Biol. Chem. 264: 5031-5035.

Pelletier, J. and N. Sonenberg. 1986. The involvement of mRNA secondary structure in protein synthesis. Biochem. Cell. Biol. 65: 576-581.

Pohjanpelto, P. and E. Holtta. 1990. Deprivation of a single amino acid induces protein synthesis-dependent increases in c-jun, c-myc, and ornithine decarboxylase mRNAs in Chinese hamster ovary cells. Mol. Cell. Biol. 10: 5814-5821.

Prats, H., M. Kaghad, A.C. Prats, M. Klagsburn, J.M. Lelias, P. Liauzun, P. Chalon, J.P. Tauber, F. Amalric, J.A. Smith, and D. Caput. 1989. High molecular mass forms of basic fibroblast growth factor are initiated by alternative CUG codons. Proc. Natl. Acad. Sci. 86: 1836-1840.
Prochownik, E.V. and J. Kukowska. 1986. Deregulated expression of $\mathrm{c}-\mathrm{myc}$ by murine erythroleukaemia cells prevents differentiation. Nature 322: 848-850.

Ramirez, M., R.C. Wek, and A.G. Hinnenbusch. 1991. Ribosome association of GCN2 protein kinase, a translational activator of the GCN4 gene of Saccharomyces cerevisiae. Mol. Cell. Biol. 11: 3027-3036.

Rao, C.D., M. Peci, K.C. Robbins, and S.A. Aaronson. 1988. The 5 ' untranslated sequence of the c-sis/platelet-derived growth factor 2 transcript is a potent translational inhibitor. Mol. Cell. Biol. 8: 284-292.

Saris, C.J.M., J. Domen, and A. Berns. 1991. The pim-1 oncogene encodes two related protein-serine/threonine kinases by alternative initiation at AUG and CUG. EMBO /. 10: 655-664.

Schubach, W. and M. Groudine. 1984. Alteration of c-myc chromatin structure by avian leukosis virus integration. Nature 207: 702-708.

Scorsone, K.A., R. Panniers, A.G. Rowlands and E.C. Henshaw. 1987. Phosphorylation of eukaryotic initiation factor 2 during physiological stresses which affect protein synthesis. $J$. Biol. Chem. 262: 14538-14543.

Shay, N.F., H.S. Nick, and M.S. Kilberg. 1990. Molecular cloning of an amino acid-regulated mRNA (amino acid starvation-induced) in rat hepatoma cells. $J$. Biol. Chem. 265: 17844-17848.

Skinner, M.K. and M.D. Griswold. 1983. Fluorographic detection of radioactivity with 2,5-diphenyloxazole in acetic acid and its comparison with existing procedures. Biochem. I. 209: 281-284.

Spencer, C.A. and M. Groudine. 1991. Control of c-myc regulation in normal and neoplastic cells. Adv. Cancer Res. 56: 148.

Spotts, G.D. and S.R. Hann. 1990. Enhanced translation and increased turnover of $c-m y c$ proteins occur during differentiation of murine erythroleukemia cells. Mol. Cell. Biol. 10: 3952-3964.

Wek, R.C., B.M. Jackson, and A.G. Hinnebusch. 1989. Juxtaposition of domains homologous to protein kinases and histidyl-tRNA synthetases in GCN2 protein suggests a mechanism for coupling GCN4 expression to amino acid availability. Proc. Natl. Acad. Sci. 86: 4579-4583.

Williams, N.P., A.G. Hinnebusch, and T.F. Donahue. 1989. Mutations in the structural genes for eukaryotic initiation factors $2 \alpha$ and $2 \beta$ of Saccharomyces cerevisiae disrupt translational control of GCN4 mRNA. Proc. Nat1. Acad. Sci. 86: 7515-7519.

Xiao, J.H., I. Davidson, H. Matthes, J. Garnier, and P. Chambon. 1991. Cloning, expression, and transcriptional properties of the human enhancer factor TEF-1. Cell 65: 551-568. 


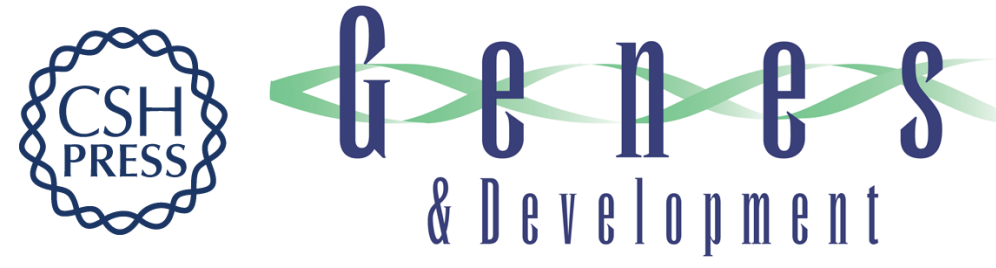

\section{Translational activation of the non-AUG-initiated c-myc 1 protein at high cell densities due to methionine deprivation.}

S R Hann, K Sloan-Brown and G D Spotts

Genes Dev. 1992, 6:

Access the most recent version at doi:10.1101/gad.6.7.1229

References This article cites 43 articles, 23 of which can be accessed free at:

http://genesdev.cshlp.org/content/6/7/1229.full.html\#ref-list-1

License

Email Alerting

Service

Receive free email alerts when new articles cite this article - sign up in the box at the top right corner of the article or click here.

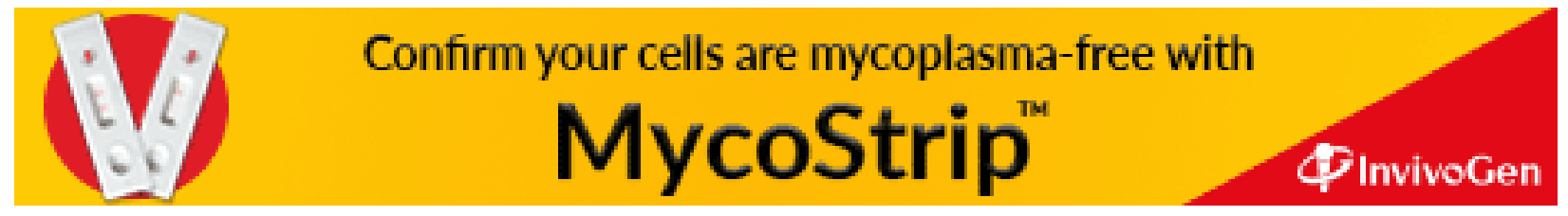

